\title{
Serat Tata Cara: The Function of Ubarampe Nourishment in Pregnancy Ritual as Javanese Ancestral Heritage
}

\author{
R Rahmawati' ${ }^{1}$, T I Setyani \\ ${ }^{1,2}$ Universitas Indonesia, Depok, Indonesia \\ E-mail: turita.indah@gmail.com
}

\begin{abstract}
Selamatan or traditional ritual in life of Javanese is a timeless heritage. In each selamatan can not apart from it is equipment or ubarampe provided, for example the ubarampe for pregnancy ritual. The focus of the study is ubarampe nourishment that should be provided from one to nine months pregnancy. The aim of the study is to reveal awareness the function of ubarampe nourishment in pregnancy ritual contained in Serat Tata Cara (Ki Padmasusastra). This study uses the semiotic theoretical framework in the qualitative paradigm with the literature review method. The results of the study indicate that ubarampe nourishment in the pregnancy ritual from one to nine months is representing the harmony of food intake needs of mother according to gestational age. That shows that since the ancient times, Javanese ancestry heritage had thought about the safety of mother as well as the fetus by providing food intake as much as each gestational age need. The food intake is manifested in ubarampe nourishment in every pregnancy ritual. Therefore, awareness is needed that ubarampe nourishment in pregnancy ritual has a functions that is still very relevant today.
\end{abstract}

Keywords: Ubarampe; Nourishment; Pregnancy Ritual; Heritage; Serat Tata Cara

\section{INTRODUCTION}

Human life cycle begins with the stage of birth and will end with death. Koentjaraningrat says, many ethnics in the world believe that every transition from one life stage to the next stage is a crisis period that is serious and dangerous, both are real and supernatural. Therefore, traditional ceremonies are called crisis rites or rites de passage (transitional ceremony) to reject occult dangers that threaten individuals and their communities [1], [2]. By carrying out the traditional ceremonies, the community hopes to obtain safety at the stage of life that will be passed. 
The stages of life that must be passed by humans are experiencing a period of growth in the maternal womb. In the stages of the human life cycle, every community has different cultural ways to understand and respond to fetal growth (pregnancy) and baby birth process that have been practiced long before the entry of biomedical systems in their community [3]. The cultural ways of community, especially Java in understanding and responding these phenomenon by carrying out a pregnancy ritual. The pregnancy ritual begins from the first month of pregnancy and is called a one-month selamatan. Then two and three months selamatan, four months selamatan, five months selamatan, six and seven months selamatan (tingkeban), eight months and nine months selamatan.

The selamatans is arranged in Serat Tata Cara. The rule is about how the pregnancy ritual are held along with the equipment or ubarampe that must be provided. The ubarampe consist of various types, such as plant-type equipment, item equipment, and type of equipment that can be consumed (called ubarampe nourishment). In the serat also regulated the rule for the implementation of pregnancy ritual of one to nine months during pregnancy.

Serat Tata Cara is one of the texts that describes the tradition that are still inherent in Javanese community. The text contains a traditional ceremony of human life cycle from the time of pregnancy to death. Serat Tata Cara is written by Ki Padmasusastra in Surakarta in the end 19th century until the beginning 20th century. Serat Tata Cara contains conversations between several figures and each character represents role in the family.

Today there are several studies about life cycle ritual of the Javanese community, among other research conducted by Venny Indria (2008) which reveals the description of procedure and about life cycle found in Serat Tata Cara during pregnancy until adolescence to matchmaking phase. In 2010, Fitri Phuspita discussed about pregnancy ritual and baby birth contained in the Teks Platenalbum Yogya. In addition, there are books that have been published such as a book written by Sutrisno S. Utomo in 2005 entitlted Upacara Daur Hidup Adat Jawa, revealing about tradition that are often carried out by Javanese community from birth to death. Books by Sumarno and Tri Mumfangati in 2016 entitlted Potret Pengasuhan Anak Dalam Kandungan Hingga Remaja Pada Masyarakat Jawa Kajian Serat Tata Cara.

Several literature reviews conducted, there are studies reveal the philosophical content of ubarampe at pregnancy ritual as in the study written by Benny Prabawa in 2012 and Rellin D.E. However, until this study was written, no studies have been found that discussed the function of ubarampe nourishment in the pregnancy ritual. Therefore, this study will reveal the function of ubarampe nourishment in pregnancy ritual from one to nine months of pregnancy in Serat Tata Cara by Ki Padmasusastra. By knowing the functions of ubarampe nourishment in the pregnancy ritual, society in general and Javanese community in particular, have an awareness that since the ancient times, Javanese ancestry heritage had thought about the safety of mother as well as the fetus.

\section{METHOD}

This study uses a qualitative method to do a literature review and semiotic theory by Rolland Barthes. The first step is to do divide the text into reading unit or lexia, then do lexias grouping to make it easier analysis [4]. The book entitled Ki Padmasusastra: Serat Tata Cara is transliterated by Sudibjo Z.H. and translated by Sunarko H. Puspito in 1980 as a source of data in this study and can be considered as accurate data. 


\section{RESULT and DISCUSSION}

In pregnancy ritual, there are various kinds of ubarampe nourishment that should be provided by the family of mother, both as food intake for mother and should be distributed to kinsman and close neighbors. Ubarampe which is used as food intake for mother in Serat Tata Cara every month is different. Ubarampe nourishment that should be provided in the first month of pregnancy ritual is jenang sum-sum. Jenang sum-sum texture is soft and easy to digest. Jenang is made from rice flour and wheat flour mixed with coconut milk and coconut sugar. The rice flour and wheat flour can increase mother's energy. Coconut sugar and coconut milk in jenang are also believed to neutralize queasy and puke. This is accord with the condition of mother in the first trimester who will often queasy and loss of appetite. If mother occasionally have queasy and puke, try to keep eating small portions but often [5]. Eating jenang sum-sum can be implemented with small but frequent portions so that food intake at this time is still fulfilled.

The growth of the fetus in the first trimester is still slow so that the nutritional needs for fetus growth have not been so great [6]. Expectant mother can consume jenang sum-sum as food intake that contains carbohydrates. Coconut sugar and coconut milk contain fat and protein needed by mother. The content of brown sugar is also believed to be an energy source to increase strength. Coconut sugar is often used by mountaineer as food intake to increase physical strength when climb the mountains.

For second and third month of pregnancy, the pregnancy ritual is held in the same time. Ubarampe nourishment that should be provided in Serat Tata Cara are sekul janganan, pelas kedhele, bongko gudhe, ampas jangan ladha kluwih, sambel puyang, sambel laos, sambel kedhele, sambel wijen, sambel gepeng, sambel kluwak, cabuk, gereh pethek bakaran, tigan 1 kasigar 5, jenang abrit lan pethak, jenang baro-baro, jajan pasar as kembang boreh, opak angin, pisang pulut, pala kependhem (uwi, gembili, kimpul, ampas kelapa kadamel manca warni), carabikang, kupat luwar satunggal and sekul janganan.

Sekul janganan is rice which is surrounded by vegetables, such as beans, bean sprouts, kale, long bean leaves, and sliced papaya mixed with grated coconut which is seasoned. Pelas kedhele is soybeans mixed with grated coconut, while bongko gudhe is gudhe beans mixed with grated coconut. Ampas jangan ladha kluwih is made from young jackfruit. Sambel puyang, sambel laos, sambel kedhele, sambel wijen, and sambel kluwak are sambal made from puyang, ginger, soybean, sesame, and kluwak.

Sambel gepeng is a sambal made from cowpea and salted fish. Tigan 1 kasigar 5 is boiled egg which is cut into 5 parts. Jenang abrit and jenang pethak is red and white jenang made from rice flour and wheat flour mixed with brown sugar and white sugar. Jenang baro-baro is made from bran flour which is topped with slices of brown sugar and grated coconut. Kembang boreh consist of opak angin and gedhang pulut. Opak angin is crackers made from sticky rice and wheat flour cooked without oil. Pala pendhem consist of tubers as uwi, gembili and kimpul, while carabikang is a traditional cake made from rice flour, white flour and tapioca cooked with eggs and coconut milk. Ketupat and sega janganan are made from rice served with vegetables are also complete the ubarampe nourishment of the second month of pregnancy ritual.

Ubarampe nourishment the second month pregnancy is dominated by rice, flour, wheat flour, bran flour, vegetables, sesame seeds, eggs, salted fish, and tubers. Entering second months of pregnancy, mother should increase food intake. This is accordance with the ubarampe that 
should be provided as carbohydrates obtained through consume food made from rice, flour, tapioca, wheat flour, with variety of food types, so increase variety of food for mother. Johanna Savitri says that extra energy needed during pregnancy to support the increasing metabolism and growth of womb organ development fetus and placenta. The use of energy is very minimum at the beginning of the pregnancy and increase in the end of trimester and continued until just months [7].

Every ubarampe that should be provided has benefits that affect in the fetus. Vegetables like beans is full of fiber that can extend the satisfied and avoid constipation. Protein in the nuts, eggs, fish, and sesame is an important in fetus growth, that is in the growth of the placenta and amnion (fetal membrane). Vegetables are also provided contain vitamin A, vitamin E, vitamin $\mathrm{C}$ and vitamin $\mathrm{K}$, as well as iron that also supports health of expectant mother. Increasing the quantity of food intake consumed is also needed in the pregnancy [5],[6].

In the fourth month of pregnancy, the ubarampe nourishment that should be provided in pregnancy ritual is sekul punar, maesa satunggal, sambel goreng and kupat sakawan. Sekul punar is rice-cooked with turmeric. Sekul punar usually served with side dishes such as slices of fried egg, serundeng (relish of grated coconut and spices), fried peanuts, kering tempe (fermented soybean cake), fried chicken and vegetables. Maesa satunggal is buffalo meat that is cooked with mixture of innards a bit and one eye of buffalo. Sambel goreng is sambal made from chilli peppers and tomatoes are mixed with potatoes and chicken liver or meat or chicken, or a mixture of all there.

Sekul punar and kupat sakawan contain carbohydrates. Maesa satunggal contain protein for expectant mother. In addition to protein, maesa satunggal contains fat, iron, tiamin (B1), niasin (B3), metionin (B12) can support the necessity of mother. Sambel goreng contains minerals such as iron which is good for the growth of red blood cells and vitamin $\mathrm{C}$ that are important for the formation of the integrity of the tissue [5],[6].

In the fifth month of pregnancy, the ubarampe nourishment that should be provided in pregnancy ritual are sekul janganan, uler-uler, enten-enten, sekul punar, ulam gorengan or ulam-ulaman, and rujak crobo. Sekul janganan is rice which is surrounded by vegetables such as ubarampe nourishment in the second month of pregnancy. The vegetables are beans, bean sprouts, kale, long bean leaves, and sliced papaya mixed with grated coconut which is seasoned. Uler-uler is made from rice flour and glutinous flour are mixed with water and given a variety of colors. As a sauce to eat uler-uler it is given brown sugar and grated coconut so called entenenten. The ubarampe nourishment also should be distributed to family and neighbors are to inform five months of the pregnancy. The ubarampe nourishment are nasi punar, meat or fried fish, or any kind of meat, sekul janganan, uler-uler and a little of enten-enten, and rujak cobro. Rujak cobro is salad fruit with seasoning sunti kencur.

Sekul janganan, sekul punar, uler-uler dan enten-enten are ubarampe nourishment that contains carbohydrates. Vegetables that should be provided along with the rice, contain a lot of vitamin and the other such as iron, protein, as described in previous months. Likewise, ulamulam contains a lot of protein, iron, fat, tiamin (B1), niasin (B3), metionin (B12) and also a lot of vitamin can be found in the rujak cobro.

Entering the sixth and seventh month of pregnancy (mitoni or tingkeban). Ubarampe nourishment that should be provided are apem kocor, sega janganan, tumpeng robyong, jenang abang, jenang baro-baro, jajan pasar, sriyatan, penyon, sampora and pring sedhapur. Apem kocor is a cake made from rice flour. Apem kocor served with juruh santen, made from brown 
sugar and coconut milk. Tumpeng robyong is ceremonial dish of yellow rice served in a cething that on the top of cone embed a piece of buffalo meat and a egg. In adddition, should be provided ubarampe nourishment such as salted egg, crackers, unripe vegetables, chilli, eggplant and nuts. Sriyatan is ubarampe nourishment made by sesame, soybean, nuts, cengkaruk gimbal (rice that has been drained) cooked without oil, mixed with sugar and kembang pari (glutinous rice flour cooked without oil and mixed with coconut and brown sugar). Penyon, sampora and pring sedhapur are cake made from flour as the main ingredient.

At this time, ubarampe nourishment that should be provided is dominated by nourishment made from rice, flour, rice flour, glutinous rice flour, vegetables, beans, sesame, coconut milk, brown sugar, eggs, buffalo meat and salted fish. Rice and all kinds of flour are ingredient that contains of carbohydrates. While vegetables, sesame, and nuts are contains of vitamins, fiber, folate, and iron are good for development of the fetus to expectant mother. The buffalo meat, eggs, and salted fish also contains protein, fat, and iron.

Ubarampe nourishment that should be provided in the eighth month is bulus angrem. Bulus angrem is klepon and srabi pethak served with grated coconut. Klepon is steamed rice cake filled with brown sugar. Srabi pethak is rice flour pancake. The ubarampe nourishment eight months of pregnancy that should be provided by the family of expectant mother not as diverse as ubarampe in the previous months. This is because at the third trimester of pregnancy, a baby begin in position to be born. Baby is ready for life in the world, although the chances of survival is not large [5].

Pregnancy ritual of ninth months is the last ritual, held before the baby is born. Ubarampe nourishment that should be provided is jenang ceprot and dhawet plencing. Jenang ceprot is jenang made from rice flour mixed with brown sugar and steamed with banana. Dhawet plencing is dhawet cendol mixed with coconut milk and brown sugar.

Jenang ceprot and dhawet plencing are ubarampe nourishment from rice flour. Rice contains carbohydrates that is most often consumed for pregnancy ritual in Serat Tata Cara. Coconut milk is the food intake full of fat, protein, calcium, and minerals such as iron and phosphorus. Fats as a reserve of energy and protein is important in establishment of cell tissue and regeneration of tissue. Calcium and phosphorus is important because in the third trimester occurs maximum growth of bones and teeth in the fetus [5].

Pregnancy is an investment that need to be prepared. Nutrition has important to support the growth and development of the fetus [5]. In other words, the food intake needed by a expectant women should be considered seriously. Referring to Serat Tata Cara, revealed that since the ancient times, Javanese ancestry heritage had thought about the safety of mother as well as the fetus by providing food intake as much as each gestational age need. It is represented in ubarampe nourishment of pregnancy ritual before the practice biomedical enter into their community. The food intake strong is important to supportive physical and mental health development of the fetus at the beginning of the pregnancy [8].

Based on Panduan Gizi Seimbang Kementrian Kesehatan RI tahun 2014, carbohydrate, protein, and fat, is a nutrient of macro that needed by expectant mother [9]. In the ubarampe nourishment should be provided by the family, each part has at least three nutritional components of the macro. So that, the ancestors of the Java community have shown their intellect to response the pregnancy in their community. They are not only creating symbols that contain philosophical values, but also consider the food intake of the mother because they realize how important it is food intake for expectant mother. Through the pregnant ritual from one to 
nine months in Serat Tata Cara, Javanese community has inherited the wisdom of ancestral cultures which is important to be preserved and disseminated. Because up to this time ubarampe that should be provided is still relevant as the fulfillment of the needs mother and her fetus. Therefore, this study is expected to provide awareness for the general community, particularly Java community that ubarampe nourishment of the pregnancy ritual has a very important function for mother and her fetus.

\section{CONCLUSION}

Through ubarampe nourishment of ritual pregnancy, which held by the family of expectant women, apparently Javanese ancestral community has been considering the food intake for expectant mother before the biomedical system enter into their community. The conclusion of this study is that ubarampe nourishment of ritual pregnancy from one to nine months in Serat Tata Cara is a representation of food intake needs for expectant mother in accordance with the age of her pregnancy.

Based on short analysis related to the function of ubarampe nourishment in Javanese pregnancy ritual, can provide awareness to the community that the pregnancy ritual is still very relevant to be held today. Although it is realized there are limitations research, so this research needs to be more developed, but at least provide a significant contribution to the development of knowledge in the present. Especially the knowledge will be importance of heritage as a local cultural potential that still has benefits for the life of next generation.

\section{REFERENCES}

[1] Koentjaraningrat, Beberapa Pokok Antropologi Sosial. Jakarta: Dian Rakyat, 1990.

[2] B. Busro and H. Qodim, "Perubahan Budaya dalam Ritual Slametan Kelahiran di Cirebon, Indonesia," J. Stud. Agama dan Masy., vol. 14, no. 2, pp. 127-147, Sep. 2018.

[3] S. Meutia, Kehamilan, Kelahiran, Perawatan Ibu dan Bayi dalam Konteks Budaya. Depok: UI Press, 1998.

[4] J. Lantowa, N. Marahayu, and Khairussibyan, Semiotika: Teori, Metode, dan Penerapannya dalam Penelitian Sastra. Yogyakarta: Deepublish, 2017.

[5] S. Fikawati, A. Syafiq, and K. Karima, Gizi Ibu dan Bayi. Jakarta: Rajawali Press, 2015.

[6] Wiryo Harnanto, Peningkatan Gizi Bayi, Anak, Ibu Hamil, dan Menyusui dengan Bahan Makanan Lokal. Jakarta: Sagung Seto, 2000.

[7] J. Savitri, Pengaruh Status Gizi dan Diet Ibu Hamil terhadap Tumbuh Kembang Janin dalam Gizi Ibu dan Bayi: Peningkatan Mutu. Jakarta: FK UI, 1986.

[8] World Health Organization, "Comprehensive Implementation Plan on Maternal, Infant and Young Child Nutrition," World Health Organization. [Online]. Available: https://www.who.int/nutrition/publications/CIP_document/en/. [Accessed: 16-Dec2018].

[9] Kementrian Kesehatan RI Direktorat Jenderal Kesehatan Masyarakat Direktorat Gizi Masyarakat, "Pedoman Gizi Seimbang Kementrian Kesehatan RI tahun 2014," Kementrian Kesehatan RI Direktorat Jenderal Kesehatan Masyarakat Direktorat Gizi Masyarakat. [Online]. Available: http://gizi.depkes.go.id/pgs-2014-2. [Accessed: 16Dec-2018]. 